\title{
PROC Gene
}

National Cancer Institute

\section{Source}

National Cancer Institute. PROC Gene. NCI Thesaurus. Code C102824.

This gene is involved in the modulation of blood coagulation. 